\title{
J(e)
}

\begin{tabular}{||l||c|c||}
\hline Received 08.11.2020 & & JOTS \\
$5 / 1$ \\
\hline \hline Accepted 20.11.2020 & Review & $2021: 220-233$ \\
\hline \hline Published 10.01.2021 & & \\
\hline
\end{tabular}

\section{Sertkaya, O. F. Dede Korkut Kitabı Üzerine Araştırmalar ve İncelemeler, İstanbul: Bilge Kültür-Sanat, 2020, ss. 368, ISBN: 978-625-7201-07-0}

\author{
Hülya UzUNTA ${ }^{*}$ \\ Trakya University (Edirne/Turkey) \\ E-mail:hulyauzuntas@trakya.edu.tr
}

"İlim âleminde ve Türk dili ve edebiyatı alanında Dede Korkut Kitabı veya kısaca Dede Korkut adı ile tanınan eser bir destanî Oğuz hikâyeleri mecmuasıdır" (Ergin, 2011: 1). Bu hikâyelerde, Oğuz beylerinin başlarından geçen çeşitli maceralar (Ergin, 2011: 23) destanî bir üslupla anlatılmıştır.

Dede Korkut Kitabı'nın ilim âlemince bilinen ilk yazması Dresden Krallık kütüphanesinde Henricus Orthobius Fleischer tarafından bulunan ve bir giriş ile on iki hikâyeden müteşekkil Kitâb-ı Dedem Korkud 'Alâ Lisân-ı Tâife-i Oğuzân başlıklı Dresden yazmasıdır. ${ }^{1}$ Yazmayı ilim âlemine tanıtan ve üzerinde ilk çalışmayı yapan ise, aynı zamanda 1815 yılında yazmanın bir kopyasını da çıkaran Heinrich Friedrich von Diez olmuştur. ${ }^{2}$ Diez'in ardından 1859 yllında yazmanın Theodor Nöldeke tarafından ikinci (Ergin, 2011: 56-57; Sertkaya, 2019: 24; Sertkaya \& Uzuntaş, 2020: 104), yirminci yüzyılın son çeyreğinde ise Azerbaycanlı bir hattat tarafından üçüncü istinsah nüshası hazırlanmıştır (Sertkaya, 2019: 26; Sertkaya \& Uzuntaş, 2020: 106).

Dresden yazması ile ilgili çalışmalar devam ettiği sırada, bir giriş ile Dresden yazmasında da geçen altı hikâyeden müteşekkil ikinci Dede Korkut

ORCID ID: 0000-0003-2306-5483.

Yazmanın içeriği ile ilgili bk. Ergin, 2011: 65.

Daha geniş bilgi için bk. Ergin, 2011: 56-57; Sertkaya, 2019: 22-24; Sertkaya \& Uzuntaş, 2020: 102-103. 


\section{J(৫)}

yazması Ettore Rossi tarafından Vatikan Kütüphanesi'nde bulunarak ilim âlemine tanıtılmıştır (Ergin, 2011: 61). Vatikan yazması olarak bilinen bu yazma, Hikâyet-i Oğuznâme-i Kazan Beg ve Gayri (Ergin, 2011: 158 [2]) başlı̆̆ını taşır.

Dede Korkut Kitabı'nın bazı araştırıcılar tarafından "Dede Korkut Kitabı'nın üçüncü nüshası", bazıları tarafından ise "Ankara nüshası" olarak adlandırılan (Sertkaya, 2019: 26; Sertkaya \& Uzuntaş, 2020: 106; Ercilasun, 2019: 9) Arap harfli 22 sahifelik bir yazmasının da Türk Tarih Kurumu kütüphanesinde (I/261) kayıtlı olduğu bilinmektedir. ${ }^{3}$

Dede Korkut Kitabi'nda geçen hikâyelerden bazılarının muhtelif coğrafyalarda versiyonlarına da rastlanmaktadır. Versiyon metinler olarak adlandırılan (Sertkaya, 2019: 26; Sertkaya \& Uzuntaş, 2020: 106) bu yazmalardan başka Dresden ve Vatikan yazmaları ile paralel yapı teşkil eden Arap harfli bir yazma ise 2018 yılının Aralık ayında Veli Muhammed Hoca tarafından Tahran'da bir kitapçıdan satın alınmıştır. Dijital ortama aktarılan el yazması metin kopyaları Veli Muhammed Hoca tarafından bazı araştırmacılara gönderilmiş, böylece Dede Korkut Kitabi'nın bu yeni el yazmasından haberdar olunmuş ve kısa sürede de farklı araştırmacılar tarafından yazma ile ilgili çeşitli yayınlar yapilmıştır. ${ }^{4}$

Dede Korkut Kitabı üzerinde uzun yıllar çalışan araştırmacılardan Orhan Şaik Gökyay, "Dede Korkut kitabı ve konusu yalnız benim değildir. O hepimizindir." (Gökyay, 2006: 16) diyerek Dede Korkut hikâyelerinin ortak bir dil, edebiyat, folklor, tarih ve kültür mahsulü olarak teşekkül ettiğini vurgulamaktadır.

Bugün bilinen ilk yazmaları Avrupa kütüphanelerinde bulunan ve ilk yayınları da Avrupalı araştırmacılar tarafından yapılmış olan Dede Korkut yazmaları üzerindeki yayın faaliyetlerini bilhassa Türkiye ve Azerbaycanlı bilim

3 Mevcut yazma, Osman Fikri Sertkaya tarafından kelime değişiklikleri, kelime takdim tehirleri, Dresden yazmasında olmayan metin parçalarının yer alması gibi nedenler göz önünde bulundurularak Dresden yazmasından farklı bir dip nüshaya dayanan varyantı olarak değerlendirilmiştir (2019: 26; Sertkaya \& Uzuntaş, 2020: 106).

4 Araştırmacılar tarafından muhtelif isimlerle anılan yazma ile ilgili müstakil yayınlar yapılmış olmakla beraber, el yazması metnin sekiz ayrı neşri yapılmıştır. Yazmanın isimlendirilmesi ve neşirleri için bk. Sertkaya \& Uzuntaş, 2020: 9-10. 


\section{ग(৫)}

insanları tarafından hazırlanan yayınlar takip etmektedir. ${ }^{5}$ Türkiye'de Dede Korkut Kitabı üzerine yayımlanan son çalışma, Osman Fikri Sertkaya'ya aittir.

Osman Fikri Sertkaya'nın Dede Korkut Kitabı hakkındaki bu yayını, bugüne değin eser üzerine çeşitli dergi ve kitaplarda yayımlanan ve ilk defa bu çalışmada yayımladığı müstakil araştırma ve inceleme yazılarını, Azerbaycan-Türkiye arasında yapılan Dede Korkut konulu ikili kolokyumların sunuş, açış-kapanış konuşmalarını ve Dede Korkut'la ilgili çeşitli yazıları / yazışmaları ihtiva eden, Bilge Kültür Sanat yayınları tarafından 20 Ekim 2020 tarihinde ilk baskısı yapılan Dede Korkut Kitabr Üzerine Araştırmalar ve İncelemeler isimli 368 sahifelik çalışmasıdır.

Eserin, Dede Korkut Kitabı'nın Dresden yazmasındaki Kañlı Koca oğlu Kan Turalı boyunun ana karakterleri olan Kan Turalı ve Selcen Hatun'un temsilini içeren ön kapak resmi, mezkûr boydaki bir soylamanın

Tartanda bir ok-ile (yiğit seni) namlar idüm

Demrensüz (bir) ok ile yiğit seni sınar idüm

mısraları (D102a/4-5) ile tamamlanmıştır. İç Kapak sahifesinden (s. 3) sonra, "Prof. Dr. Ahmet Caferoğlu, Dr. Honoris Causa Orhan Şaik Gökyay, Prof. Dr. Muharrem Ergin'in aziz hatıralarına" ithaf edilen eserin ithaf sahifesi (s. 5), ardından İçindekiler listesi (s. 7-8) yer alır. İçindekiler listesini, Sertkaya'nın Dede Korkut hikâyeleri ile tanışmasını anlattığı ve 1988-2019 yılları arasında düzenlenen Uluslararası Dede Korkut Kolokyumları ile eser içeriği hakkında bilgi verdiği Sunuş (s. 9-14) kısmı takip eder. Sunuş'tan sonra eserin ana bölümünü oluşturan ve farklı tarihlerde kaleme alınan 26 yazı yer alır.

\section{1. “Dede Korkut Kitabı'nın Vatikan Nüshasının Latince, Arapça, Farsça ve Türkçe Metin Dışı Kayıtları" (s. 15-28)}

Hikâyet-i Latîfe-i U'cûbe ve Mahcûbe-i Zarîfe ve Hikâyet-i Oguz-nâme-i Kazan Beg ve Gayrı başlıklı iki metin ihtiva eden Vatikan yazmasının 1a, 1b, 107b, 108a, 110b sahifelerinde bulunan Latince, Arapça, Farsça ve Türkçe on yedi kaydın incelendiği bu yazıda, tıpkıbasımlarına da yer verilen kayıtlar numaralandırılarak listelenmiş, Arap harfli olanlar Latin harflerine aktarılmış ve

Dede Korkut Kitabı ile ilgili başlıca yayınlar için bk. Ergin, 2011: 56-64; Gökyay, 2006: 648-694; Erdem, 1998: 50-72; Sertkaya, 2006: 11-23. 


\section{J(e)}

Latince, Arapça, Farsça kayıtların Türkiye Türkçesine çevirisi yapılmıştır. Metin dışı kayıtların değerlendirildiği sonuç bölümünde kayıtlardaki bilgilerden hareketle yazmanın Vatikan kütüphanesine intikaline kadarki yedi sahibi sıralanmıştır.

\section{2. "Dede Korkut Kitabı'nın Dresden Nüshasının Türkçe, Latince, Farsça} ve Arapça Metin Dışı Kayıtları" (s. 29-44)

Dresden yazmasının 1a, 1b, 2a, 155a (155b) ${ }^{6}$ sahifelerindeki Türkçe, Latince, Farsça ve Arapça yazılan on beş metin dışı kayıtla ilgili önceki okuma ve anlamalar değerlendirildikten sonra tıpkıbasımlarına da yer verilen kayıtlar numaralandırılarak listelenmiş, Arap harfliler Latin harflerine aktarılmış ve 2-3, 5-7, 9-15. kayıtlar Türkiye Türkçesine çevrilmiştir.

\section{3. “Dede Korkut Kitabı'nda Dörtlük Türü ve Hece Vezni Var Mı?" (s.} 45-54)

Dede Korkut Kitabi'nın Bamsı Beyrek boyunda geçen iki soylama (D57a/6-12, V79b/11-80a/1; D56b/1-6, V79b/1-3) ${ }^{7}$ incelenmiştir. İlk soylama üzerinde yapılan daha evvelki okuma çalışmaları sıralandıktan sonra Sertkaya $4+3=7$ 'li hece vezniyle dörtlük şeklindeki okuyuşunu, dipnotlarda belirttiği gerekçeler ile birlikte vermiştir. ${ }^{8}$ Dresden ve Vatikan yazmalarındaki tıpkıbasımlarına da yer verilen (s. 48-49) ikinci soylamanın Ergin ve Gökyay tarafından yapılan okuma ve anlamlandırmaları verildikten sonra soylama, Sertkaya tarafından tespit edilen hece vezni ve kafiye düzenine göre yeniden okunarak anlamlandırılmış (s. 51-52) ve soylamanın daha iyi anlaşılmasını sağlayacak açıklamalar listesi eklenmiştir (s. 53-54). ${ }^{9}$ Bu çalışması ile Sertkaya, "Dede Korkut Kitabindaki manzum parçalarda hece vezni ile söylenmiş, dörtlüklerin var olduğuna”(s. 48) dikkat çekmiştir.

6 İlgili düzelti için bk. s. 43.

7 Dresden ve Vatikan yazmalarının sahife/satır numaraları Tezcan \& Boeschoten, 2018 neşrine göre verilmiştir.

8 İlgili soylama için ayrıca bk. s. 60-63, 231-339.

9 Bugüne değin araştırmacılar tarafından farklı şekillerde okunup anlamlandırılan ikinci soylamanın son okuma, anlamlandırma ve açıklamaları için bk. s. 231-339. Mezkûr soylama için ayrıca bk. s. 7177. 


\section{ग(๑)}

\section{4. “Dr. Osman Fikri Sertkaya'nın Dede Korkut Kollokyumunu Açış Konuşması" (s. 55-56)}

1-8 Temmuz 1988 tarihleri arasında Bakü/Azerbaycan'da düzenlenen Sovyetler Birliği ile Türkiye Cumhuriyeti'nin karşllıklı imzaladığı Kültürel ve Bilimsel Değişim Programı çerçevesinde yapılan Kültür Anıtı Olarak Dede Korkut Kitabı konulu (s. 57) ilk karşılıklı kolokyuma Millî ve Milletlerarası Türkoloji Kongresi Genel Sekreteri olarak katılan Dr. Osman Fikri Sertkaya'nın kolokyum açılışında yapmış olduğu konuşma metnidir.

\section{5. "Sunuş" (s. 57-58)}

1-8 Temmuz 1988 tarihleri arasında Bakü/Azerbaycan'da düzenlenen Kültür Anitı Olarak Dede Korkut Kitabı konulu I. Sovyet-Türk Kolokyumu'nun ardından kaleme alınan yazıda kolokyum katılımcılarının listesi verilmiş, kolokyumun Türkiye ve Azerbaycan'daki edebî yankılarından bahsedilerek II. Türk-Sovyet Kolokyumu'nun Bakü kolokyumunda tayin edilen tarih-yer ve konusu duyurulmuştur.

\section{6. “Dede Korkut Kitabi'ndaki Bazı Manzum Parçaların Hece Vezni ve} Manzume Türü Açısından Değerlendirilerek Yeniden Okunması" (s. 59-78)

Dede Korkut Kitabı'ndaki manzumeler ile ilgili evvelki görüşler listelenerek manzumelerin okunmasında karşılaşılan güçlüğün sebepleri tespit edilmiş, bu sebepler "eksik mısraların ilâvesi", "eksik kelimelerin ilâvesi" ve "naşirlerin yanlış okumalarının düzeltilmesi” olmak üzere üç başlık altında değerlendirilmiştir.

"Eksik mısraların ilâvesi" alt başlığında, ilgili başlık için güzel bir örnek teşkil eden, "Dede Korkut Kitabinda Dörtlük Türü ve Hece Vezni Var Mt?" başlıklı yazıda incelenen Bamsı Beyrek boyunda geçen ilk soylama (D57a/6-12, V79b/11-80a/1) örnek verilmiştir (s. 60-63).

"Eksik kelimelerin ilâvesi" alt başlığında vezni ve yapisı tespit edilen beş soylama örnek verilmiştir (s. 63-66). Bunlar sırası ile;

Kazan Bey'in oğlu Uruz'un tutsak olduğu boyda geçen bir soylama (D66b/3$67 \mathrm{a} / 3, \mathrm{~V} 93 \mathrm{~b} / 5-8)(\mathrm{s} .64-66)$

Salur Kazan'in evinin yağmalandığı boyda geçen bir soylama (D22a/13-22b/7, V85a/12-85b/2) (s. 67-68) 


\section{J(৫)}

Derse Han oğlu Boğaç Han boyunda geçen bir soylama (D10b/12-11a/5, V62b/1-5) (s. 69)

Derse Han oğlu Boğaç Han boyunda geçen bir soylama (D18a/3-18b/5, V66b/411) (s. 70-71)

Derse Han oğlu Boğaç Han boyunda geçen bir soylama (D18b/6-19a/3, V66b/13-67a/6) (s. 70-71)'dır.

$\mathrm{Bu}$ başlık altında incelenen soylamalarla ilgili açıklamalar dipnotlarda verilmiştir.

"Naşirlerin yanlıs okumalarının düzeltilmesi" alt başlığında ilgili başlığın güzel bir örneği olan, "Dede Korkut Kitabinda Dörtlük Türü ve Hece Vezni Var Mı?" başlıklı yazıda incelenen Bamsı Beyrek boyundaki ikinci soylama (D56b/1-6, V79b/1-3) ele alınmıştır (s. 71-75).

$\mathrm{Bu}$ yazı ile, mensur bir metin olan Dede Korkut Kitabı içerisindeki manzumelerin yapısı ve veznine dikkat edilerek okunması gerektiğinin güzel bir örneği verilmiştir.

\section{7. "Sunuş" (s. 79-81)}

İstanbul Üniversitesi Türkiyat Araştırmaları Enstitüsü, Azerbaycan Elmler Akademiyası ve Azerbaycan Yazıcılar Birliği'nin işbirliğiyle 21-26 Aralık 1998 tarihleri arasında Bakü/Azerbaycan'da düzenlenen II. Milletlerarası Dede Korkut Kollokyumu'nun ardından kaleme alınan yazıda açış oturumundan kapanış oturumuna kadar gerçekleştirilen tüm oturumlar tarih ve saat sıralaması ile verilerek her oturumdaki katılımcılar ve bildiri başlıkları listelenmiştir. İstanbul Üniversitesi Türkiyat Araştırmaları Enstitüsü müdürü olarak kolokyuma iştirak eden Sertkaya'nın bu yazısı tarihî bir kayıt hüviyetinde olduğu için, benzeri diğer yazıları gibi, ayrı bir ehemmiyeti haizdir.

\section{8. "İstanbul Üniversitesi Türkiyat Araştırmaları Enstitüsü Müdürü Prof. Dr. Osman Fikri Sertkaya'nın Açış Konuşması” (s. 83-85)}

İstanbul Üniversitesi Türkiyat Araştırmaları Enstitüsü, Azerbaycan Elmler Akademiyası ve Azerbaycan Yazıcılar Birliğgi'nin işbirliğiyle 21-26 Aralık 1998 tarihleri arasında Bakü/Azerbaycan'da düzenlenen II. Milletlerarası Dede Korkut Kollokyumu'nda Prof. Dr. Osman Fikri Sertkaya'nın İstanbul Üniversitesi Türkiyat 
Araştırmaları Enstitüsü müdürü olarak yaptığı açış konuşmasının metnidir. Konuşmasının başında vefat eden korkutşinasları rahmetle yad eden Prof. Dr. Osman Fikri Sertkaya, ikinci kolokyumun katılımcısı olan Türk heyetini takdim etmiş, ömrünü Dede Korkut çalışmalarına adayan ve kendilerine pilaket takdim edilmesi kararlaştırılan âlimlere pilaket sunumunu gerçekleştirdikten sonra, Dede Korkut ile ilgili 1998 yılında Türkiye'de yapılan çalışmalar hakkında bilgi vermiştir. Bu yazı da, Prof. Dr. Osman Fikri Sertkaya'nın benzeri diğer "sunuş, açış konuşması, kapanış konuşması" yazıları gibi tarihî bir belge hüviyetinde olduğu için, ayrı bir öneme sahiptir.

\section{9. “İstanbul Üniversitesi Türkiyat Araştırmaları Enstitüsü Müdürü Prof. Dr. Osman Fikri Sertkaya'nın Kapanış Konuşması” (s. 87-88)}

İstanbul Üniversitesi Türkiyat Araştırmaları Enstitüsü, Azerbaycan Elmler Akademiyası ve Azerbaycan Yazıcılar Birliği'nin işbirliğiyle 21-26 Aralık 1998 tarihleri arasında Bakü/Azerbaycan'da düzenlenen II. Milletlerarası Dede Korkut Kollokyumu'nda Prof. Dr. Osman Fikri Sertkaya'nın İstanbul Üniversitesi Türkiyat Araştırmaları Enstitüsü müdürü olarak yaptığı kapanış konuşmasının metnidir. Kolokyumun değerlendirmesi yapılmış, emeği geçenlere teşekkür edilerek alınan kararlar açıklanmış, teklifler beyan edilmiştir.

10. “Dede Korkut Kitabinın Dresden Yazmasındaki Bazı Kelime ve Şekillerin İmlâ Özelliklerine Dayanılarak Yeniden Okunuşu ve Anlamlandırılışı Üzerine" (s. 89-112)

Dede Korkut Kitabı'nın Dresden yazması ile Dede Korkut neşir ve araştırmalarında görülen hatalar "Dede Korkut'un Dresden yazmasının müstensihine ait hatalar" ve "Dede Korkut nâşirleri ve araştırıcılarına ait hatalar" olmak üzere iki ana başlık altında değerlendirilerek bazı yeni okuma ve anlamlandırma teklifleri sunulmuştur:

\section{Dede Korkut'un Dresden yazmasının müstensihine ait hatalar}

I/1a. İmlâda başka kelime yerine yanlış yazılan kelimeler (4 örnek)

I/1b. İmlâda ayrı yazılan kelimeler (7 örnek) 


\section{ل(৫)}

I/1c. İmlâda noktalama veya diş hatası yüzünden yanlış okunan kelimeler (1 örnek)

I/2. İmlâda fazla harf veya hece yazılması yüzünden kelimenin yanlış teşhis edilmesi (listelenen 13 örnek)

I/3a. İmlâda eksik harf veya hece yazılması yüzünden kelimenin yanlış teşhis edilmesi (listelenen 37 örnek)

I/3b. İmlâda eksik kelime olması yüzünden ibârenin veya cümlenin anlaşılamaması (listelenen 28 örnek)

I/4. İmlâda noktalama işaretlerinin yanlış yere konulmasından kaynaklanan yanlış teşhisler (2 örnek [geniş bir izah ile birlikte])

\section{Dede Korkut nâşirleri ve araştırıcılarına ait hatalar}

II/1. Yanlış okuma, açıklama ve tercümeler

II/1a. Şedde'nin okunmaması (1 örnek [geniş bir izah ile birlikte])

II/1b. Şedde'nin yanlış okunması (1 örnek [geniş bir izah ile birlikte])

II/1c. / Elif harfinin /a/ yerine /i/ okunması (1 örnek [geniş bir izah ile birlikte])

II/1d. / Elif harfinin /e/ yerine /a/ okunması (1 örnek [geniş bir izah ile birlikte])

II/1e. و (Elif-Vâv) harflerinin /ö/ yerine /ü/ okunması (1 örnek [geniş bir izah ile birlikte])

II/1f. Kalın sıralı kelimeyi ince sıralı okumak (2 örnek [geniş bir izah ile birlikte])

II/2. Daha önce doğru okunan bir kelimeyi düzeltme gayesiyle yanlışa çevirmek (1 örnek)

II/3. Başkasının buluşunu veya okuyuşunu sahiplenmek yani "intihal" (2 örnek)

II/4. Kaynak eksikliği nedeniyle gözden kaçan açıklamalar ve değerlendirmeler (2 örnek).

11. "Sunuş" (s. 113) 


\section{J(৫)}

Azerbaycan Yazarlar Birliği (Azerbaycan Yazıçılar Birliği) Başkanı Anar Resuloğlu Rızayev'in 1999 yılında Ötüken yayınevi tarafından neşredilen 142 sahifelik Çağdaş Azerbaycan Türkçesi ile yazılmış Dede Qorqut adlı eserinin tanitımıdır.

12. "Dede Korkut'ta Geçen Tarıklı̆̆ Boşalmak İbaresi Üzerine" (s. 115124)

Kañll Koca oğlu Kan Turalı boyundaki bir metin parçasında (D91a/2-92a/8) geçen bazı okuma ve anlamalar listelenerek değerlendirilmiş, ardından parçada

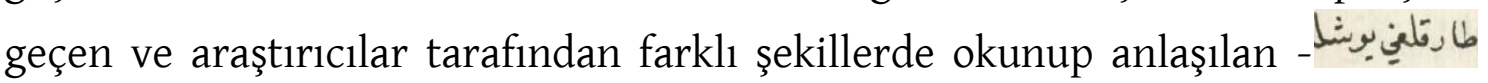
(D92a/4) deyimi ile ilgili, daha evvel yapılan izahlar da sıralanarak Sertkaya'ya ait okuma ve anlamlandırma teklifi ortaya konulmuştur.

\section{3. "Sâdettin Özçelik'e Mektup" (s. 125-140)}

Sâdettin Özçelik'in 2006 yılında Gazi Kitabevi yayınları arasından çıkan Dede Korkut Üzerine Yeni Notlar adlı çalışmasında, Sertkaya'nın “Dede Korkut'ta Geçen Tarıklı̆ı Boşalmak İbaresi Üzerine" başlıklı bildirisi ile ilgili yaptığı "değerlendirmesinin Sertkaya tarafından değerlendirildiği” 16.04.2007 tarihli mektubun tam metnidir.

\section{4. "Kitâbı Dede Korkut'ta Basat Okunan İsim Üzerine Yeni Görüşler"} (s. 141-149)

Depegöz boyunun kahramanı olan بـ 'يسا 'ın bugüne değin basāṭ okunan adının Arapça, Farsça ve Türkçe kaynaklarda geçen imlâlarından hareketle neden busāt veya pusāṭ okunması gerektiği ortaya konulmuştur.

15. "Dede Korkut Hikâyelerinde Askerlikle İlgili Moğolca Kelimeler Üzerine" (s. 151-163)

Dede Korkut hikâyelerindeki askerlikle ilgili kelimelerden 17 tanesi (bahadır, cılasun, epçin, cebe, tugulga, cıda, çomag, kalkan, sadag, balçag, namlamak, karavul, cılavı, cılbır, yılga-, ılgar, keher) açıklanarak bu kelimelerin Dede Korkut hikâyelerinde kullanıldıkları cümleler sıralanmıştır. 


\section{J(৫)}

\section{6. "Mongolian Words and Elements in the Oghuz Epic Dede Qorqut. I. (Words Related to Military)" (s. 165-172)}

"Dede Korkut Hikâyelerinde Askerlikle İlgili Moğolca Kelimeler Üzerine" başlıklı on beşinci yazının İngilizce çevirisidir. On beşinci yazıdan farklı olarak ilgili kelimelerin Dede Korkut hikâyelerinde kullanıldıkları cümleler bu yazıda yer almaz.

\section{7. “Haberler: III. Uluslararası Dede Korkut Kolokyumu” (s. 173-175)}

20-22 Haziran 2009 tarihleri arasında Bakü'de düzenlenen III. Uluslararası Dede Korkut Kolokyumu'nun ardından kaleme alınan bir değerlendirme yazısıdır. Kolokyumun oturumları ile ilgili bilgi verilmiş ve IV. Uluslararası Dede Korkut Kolokyumu'nun düzenleneceği yer ve tarih bilgisi duyurulmuştur.

\section{8. “Görülmemiş Rüyalar (2)” (s. 177-179)}

“20-22 Haziran 2009 tarihleri arasında Bakü’de düzenlenen III. Uluslararası Dede Korkut Kolokyumu'nun açllış töreninde Sertkaya'nın eş başkan olarak yaptığ 1 açış konuşmasının (s. 177 [dip. 169]) metnidir. Okuyucuları (öncesinde dinleyicileri) içine çeken etkileyici bir olay örgüsü hâkimdir.

19. "Derse Han Boyunda Geçen Bir Yetmen İkizlemesi (Sinonimi) Üzerine" (s. 181-188)

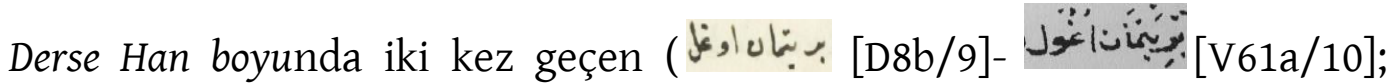

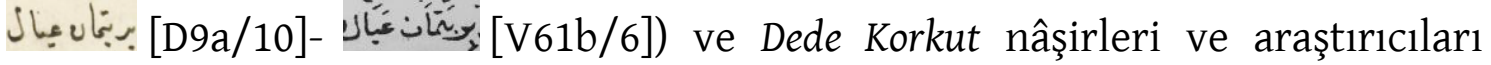
tarafından farklı şekillerde okunup anlamlandırılan بـ بـنان ibâresi ile ilgilidir. Sertkaya, sinonim (kompositum) olarak değerlendirdiği ibâreyi daha evvel yapılan çalışmalara da yer vererek yeniden açılamıştır.

\section{0. “Begrek > Beyrek Kelimesi Üzerine" (s. 189-192)}

Bamsı Beyrek boyunun kahramanının Dede Korkut nâşirleri ve araştırmacıları tarafından farklı şekillerde okunan ve açılanan ismi ile ilgilidir. İsim hakkında yapılan önceki okuma ve açıklamaları listeleyip değerlendiren Sertkaya, ismin Eski Türkçe dönemine ait metinlerdeki imlâlarına da yer vererek etimolojik izahını yapmış ve anlamlandırmıştır. 


\section{I(G)}

\section{1. "Dede Korkut İthafları ve Bazı Yazışmalar" (s. 193-213)}

İlgili yazının "ithaflar” bölümü, Dede Korkut nâşirlerinden Orhan Şaik Gökyay'ın 1938 tarihli Dede Korkut neşrini takdim ettiği Ahmet Caferoğlu ve Hüseyin Nihal Atsı'a ithafları ile Muharrem Ergin'in 1958 tarihli Dede Korkut neşrini hediye ettiği asistanı Osman Fikri Sertkaya'ya ithafını içerir (s. 193-196). Başlıkta belirtilen “bazı yazışmalar” bölümü Dede Korkut Kitabı'nın Dresden yazması ile ilgili kütüphane kayıtlarını, Vatikan yazması hakkında Muharrem Ergin ve Ettore Rossi yazışmalarını, Türk Dil Kurumu yürütme kurulunun Dede Korkut Kutlamaları Düzenleme Kurulu tarafından yayımlanması kararlaştırılan Vatikan yazmasını yayıma hazırlamak üzere vazifelendirilen Mustafa S. Kaçalin'in Hikâyet-i Oğuz-Nâme-i Kazan Bég ve Gayrı adı ile neşre hazırladığı çalışma hakkında Türk Dil Kurumu'na sunulan raporu ve Muharrem Ergin'in 1963 tarihli Dede Korkut neşrinden sonra Orhan Ş. Gökyay'ın Ergin neşrini tenkidi ile başlayan Gökyay-Ergin yazışmaları hakkındaki bilgileri, bunlardan Ergin'in Gökyay tenkidini tenkit yazısının yayımı ile ilgili yazışmaları ve Sertkaya'nın eş başkan olarak “20-22 Haziran 2009 tarihleri arasında Bakü'de düzenlenen III. Uluslararası Dede Korkut Kolokyumu'nun açılış töreninde yaptı̆̆ “Görülmemiş Rüyalar (2)" başlıklı açış konuşmasının (s. 177 [dip. 169]) bir kısmını ihtiva eder (s. 197-213).

22. "Dede Korkut Kitabı'nda Geçen Demür Güci ve Kıyan Güci veya Demür Egüci ve Kıyan Egüci İsimleri Üzerine" (s. 215-222)

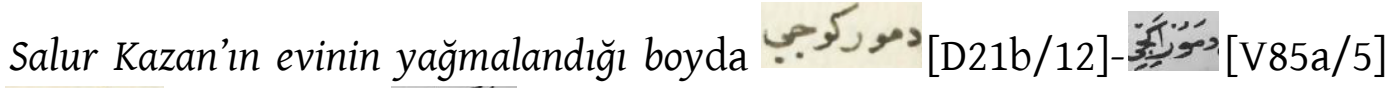

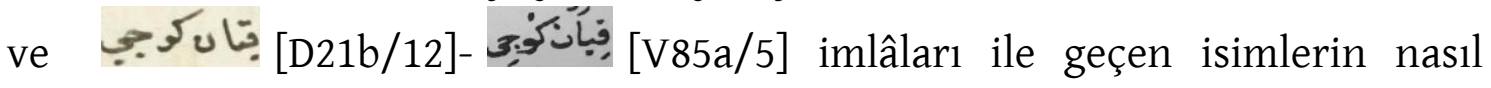
okunması gerektiği ile ilgilidir. Bu isimler ile ilgili daha evvel yapılan çalışmalara da yer veren Sertkaya, özellikle Kıyan ismini teferruatlı bir şekilde izah ederek her iki ismin okunuşu ile ilgili görüşünü gerekçeleri ile ortaya koymuştur.

\section{3. "Derse Han ile Ailesi Hakkında Son Bilgiler ve Metinde Geçen Kara} Donlu Derviş, Sayvân, Asanmış İdi Gibi Kelimelerin Yeniden Anlamlandırılışı Üzerine" (s. 223-229)

Hristiyan bir Türk olduğu ifade edilen Han'ın unvanının niçin Derse/Dérse şeklinde okunması gerektiği belirtilmiş, Derse Han'ın sülalesi ve ailesi 


\section{ग(৫)}

hakkındaki bilgilere dayanılarak Dede Korkut Kitabinda ismi zikredilmeyen Derse Han'ın hatunu ve oğlu Boğaç'ın isimlerinin tespiti yapılmış ve aynı boydaki "kara donlu derviş, sayvân, asanmış idi” ibâreleri açıklanarak anlamlandırılmıştır. Ayrıca ilgili boyda geçen "kara otağ, kara keçe, kara koyun, kuru kuru çaylara suvcı saldım" ibâreleri de değerlendirilmiştir.

\section{4. “Dede Korkut Kitabı'nda Geçen Bir Soylamanın Analizi” (s. 231-339)}

Bamsı Beyrek boyunda geçen ve bugüne değin Dede Korkut araştırmacıları tarafından farklı şekillerde okunup anlamlandırılan soylamanın (D56b/1-6, $\mathrm{V79b} / 1-3)^{10}$ Sertkaya tarafından son okuma, anlamlandırma ve açıklamalarının yapıldığı bu yazı, eser içindeki en hacimli yazıdır. Sertkaya ilgili soylamanın 1938 tarihli Orhan Şaik Gökyay okuyuşundan başlayarak 2020 yılına kadar muhtelif araştırmacılar tarafından yapılan okuma, çeviri ve açıklamaları kronolojik olarak verdikten sonra, kendi son okuma, çeviri ve açıklamalarına yer vermiştir. Soylama ile ilgili okuma ve izahların kronolojik olarak takip edilebildiği çalışmada Sertkaya'nın konuyu değerlendirme yöntemi, benzeri şekilde izaha muhtaç başka metinlerin çözümü için de yol gösterici olmuştur.

\section{5. "Dede Korkut Kitabi'nda Geçen Unutulmuş Bir Mûsikî Âleti: "Şâdılık Çalmak/Şadılık Çalmak" = "Şâdiyân" ve "Şâdiyân Çalmak". (s. 341- 348)}

Osman Fikri Sertkaya ve Yusuf Azmun tarafından müştereken hazırlanıp 11 Haziran 2020'de Uluslararası Dede Korkut Bilgi Şöleni ve Deli Dönmez'e Ad Verme Çalıstayı'nda sunulan bildiri metnidir. ${ }^{11}$ Bu yazıda Dede Korkut Kitabı'nda 7 kez geçen şâdllı çalmak ibâresi daha evvel yapılan açıklamalara da yer verilerek değerlendirilmiş, şâdılık'ın Dede Korkut neşirlerinde bahsedildiği gibi telli değil üflemeli bir mûsikî aleti olduğu ve bu mûsikî aletinin Farsça ve Türkmen Türkçesinde şâdiyân şeklinde kullanılan mûsikî aleti ile ayniliği teferruatlı bir incelemeyle ortaya konulmuştur.

\section{6. "Atatürk (Dede Korkut Ağzıyla)" (s. 349-352)}

\footnotetext{
10 İlgili soylama için ayrıca bk. s. 48-54, 71-77.

11 Basılı bildiri metni için bk. Sertkaya \& Azmun, 2020: 384-392.
} 


\section{ग(৫)}

Dede Korkut Kitabı'ndaki boylama ve soylama'ların üslubunca Prof. Dr. Ali Nihad Tarlan tarafından III. Edebiyat Gecesi için yazılmış metindir.

Eserin Dizin bölümünde (s. 353-368), eser içerisindeki şahıs isimleri, mevcut imlâlarına göre isim-soy isim şeklinde alfabetik olarak sıralanarak zikredildikleri sahife numaraları verilmiştir [Örneğin, Ayşe Gül 179 bk. Ayşegül Sertkaya (s. 355a)]. Aynı ismin farklı imlâlarına bk./krş. kısaltmaları ile göndermeler yapılarak [Örneğin, Ayşe Gül 179 bk. Ayşegül Sertkaya (s. 355a); Ayşegül Sertkaya 179, 327, 327, 333, 333 krş. Ayşe Gül (s. 355a)] eserde değişik imlâlarla kullanılan isimlere toplu olarak erişebilme kolaylığı sağlanmıştır.

\section{Sonuç}

Eserdeki 17 yazı farklı tarihlerde muhtelif dergilerde yayımlanmıştır. Bunlardan ikisi (1, 2. yazılar) Türkologiya dergisinde; dördü (3, 17, 18, 22. yazllar) Türk Dili dergisinde, biri (4. yazı) Türk Kültürü dergisinde, altısı (5, 6, 7, 8, 9, 10. yazılar) TDAY Belleten dergisinde, ikisi (11, 19. yazllar) Dede Qorqud dergisinde, biri (16. yazi) Mongolica "An International Annual of Mongol Studies"de, biri (20. yazi) Ankara Üniversitesi Dil ve Tarih-Coğrafya Fakültesi Türkoloji dergisinde yayımlanmıştır. Eserdeki 4 yazı (12, 14, 23, 25. yazılar) bildiri kitaplarında, 1 yazı (21. yazı) armağan kitabında, 1 yazı (26. yazı) müstakil çalışma olarak yayımlanmış, 3 yazı $(13,15,24$. yazılar) ise ilk kez bu çalışmada yayımlanmıştır.

“Araştırma-inceleme yazıları" olarak değerlendirilen yazılarda Dede Korkut Kitabı'ndaki pek çok konuya 1 şı tutulmuştur. Dede Korkut konulu yazıların/yazışmaların kayıtlarını içeren diğer yazılar ise tarihî birer belge hüviyetine sahip olması bakımından oldukça mühimdir.

Eserini Türkiye'nin merhum Dede Korkut araştırmacılarından hocası Ahmet Caferoğlu, Orhan Şaik Gökyay ve doktora babası Muharrem Ergin'e ithaf ederek ruhlarını şad eden Sertkaya, 11 Ağustos 2013 tarihinde yaş haddinden dolayı çalıştı̆̆ kurumdan emekliye ayrılmasına karşın, "Bilim adamı bilimden emekli olmaz" anlayışıyla ilmî çalışmalarına ara vermeden devam etmekte ve çalışkanlığı ile genç araştırmacılara örnek olmaktadır.

$\mathrm{Bu}$ örnek çalışmayı hazırlayarak Türklük Biliminin istifadesine sunan hocam Osman Fikri Sertkaya'yı kutluyor, kendisine ve eşi, hocam Ayşegül 


\section{Je)}

Sertkaya'ya, Türklük Bilimine kazandırılacak daha nice kıymetli çalışmaları hazırlayacağı sağlıklı uzun yıllar diliyorum.

\section{Kaynakça}

Ercilasun, A. B. (2019). Dede Korkutun Yeni Nüshası Üzerine Konu-BağlantılarYer-Zaman-Okuyuş. Dil Araştırmaları, 24, 7-13.

Erdem, M. (1998). Dede Korkut Türkmenistan Varyantları. Ankara Üniversitesi, Sosyal Bilimler Enstitüsü, Çağdaş Türk Lehçeleri Anabilim Dalı. [Yayımlanmamış Doktora Tezi]

Ergin, M. (2011). Dede Korkut Kitabı I: Giriş-Metin-Tıpkıbasım. 8. Baskı. Türk Dil Kurumu Yayınları.

Gökyay, O. Ş. (2006). Dedem Korkudun Kitabı. Kabalcı Yayınları.

Sertkaya, O. F. (2006). Dede Korkut Kitabı'nın Dresden Nüshasının “Giriş" Bölümü (Metnin Transkripsiyonu ve Açıllama Notları). Ötüken Neşriyat.

Sertkaya, O. F. (2019). Dede Korkut Kitabı'nın Kaç Yazma Nüshası Var? Dede Qorkud, Azerbaycan Milli Elmler Akademiyası Folklor İnstitusu, 3, 21-27.

Sertkaya, O. F. (2020). Dede Korkut Kitabı Üzerine Araștırmalar ve İncelemeler. Bilge Kültür Sanat Yayınları.

Sertkaya, O. F. \& Azmun, Y. (2020). Dede Korkut Kitabı'nda Geçen Unutulmuş Bir Mûsikî Âleti: "Şâadllık Çalmak/Şadıllk Çalmak"="şâdiyân" ve "şâdiyân Çalmak. In Uluç, G. \& Şimşek, N. D. (Ed.), Uluslararası Dede Korkut Bilgi şöleni ve Deli Dönmez'e Ad Vérme Çalıştayı Bildiriler Bétiği, 11-12 Haziran 2020 (pp. 384-392). Kutlu Yayınevi.

Sertkaya, O. F. \& Uzuntaş, H. (2020). Dede Korkut'un Günbed Yazması Üzerine Araştırmalar ve İncelemeler. Bilge Kültür Sanat Yayınları.

Tezcan, S. \& Boeschoten, H. (2018). Dede Korkut Oğuznameleri. 5. Baskı. Yapı Kredi Yayınları. 